\title{
Yeni Medyada Yeni Habercilik ve İş Modeli Arayışları: Medyascope Örneği
}

\author{
Recep Ünal \\ yardımcı doçent, mersin üniversitesi, iletişim fakültesi \\ recepunal@mersin.edu.tr
}

\section{Abstract \\ In Search of New Journalism and Business Models in New Media: The Case of Medyascope}

New media affect news production and consumption practices and lately developed applications offer new opportunities that generate changes in the news ecology. This descriptive study elaborates the online journalism project Medyascope, which was launched by journalist Ruşen Çakır following his first mobile live broadcasting experience on the eve of the general elections of June 7, 2015 through Periscope. Medyascope offers live broadcasting shows via Periscope as well as Facebook and YouTube, hosts guests from abroad via Skype connections and also transmits Periscope broadcasts of various people when it comes to important social events arising spontaneously. However, this new platform suffers from certain limitations such as the insufficient use of interactive means in social media as well as the lack of a sustainable model of income. The aim of this study is to present the structure and functioning of Medyascope, using the data obtained from in-depth interviews with Medyascope team and content analysis of programs presented between August 19 and September 3. Therefore, it is envisaged to understand

Bu makaleye referans vermek için: Ünal, R. (2017). Yeni Medyada Yeni Habercilik ve İş Modeli Arayışları: Medyascope Örneği. Galatasaray Üniversitesi Ileti-ş-im Dergisi, 26, 83107. DOI: $10.16878 /$ gsuilet.324206. 
the economic model adopted by Medyascope and to discuss whether this is sufficient for the sustainability of the project.

keywords: new media, journalism, mobile live video streaming applications, Periscope, Medyascope

\section{Résumé}

\section{En quête des nouveaux modèles d'affaires et de journalisme dans les nouveaux médias: le cas de Medyascope}

Les nouveaux médias affectent les pratiques de production et de consommation des nouvelles; les nouvelles applications offrent des nouvelles opportunités qui engendrent des changements concernant l'écologie d'information. Cette étude descriptive élabore le projet du journalisme en ligne Medyascope du journaliste Ruşen Çakır qui s'est mis à diffuser des programmes à la veille des élections générales du 7 juin 2015 à travers d'une application mobile d'émission en directe, la plate-forme Périscope. Medyascope offre des émissions en direct via Periscope ainsi que Facebook et YouTube, accueille des invités depuis l'étranger via des connections Skype et transmet également des émissions Periscope des diverses personnes quand il s'agit des importants événements sociaux surgissant spontanément. Cependant, cette nouvelle plateforme souffre de certaines limitations comme l'utilisation insuffisante des moyens d'interactivité des médias sociaux ainsi que les problèmes économiques au manque d'un modèle de financement durable. L'objectif de notre étude est de présenter la structure et le fonctionnement de Medyascope grâce à des données obtenues au moyen dientretiens approfondis avec l'équipe de la plate-forme ainsi que l'analyse du contenu des émissions présentées entre le 19 août et le 3 septembre. De ce fait, il est envisagé de comprendre le modèle de financement adopté par Medyascope et de discuter si celui-ci est suffisant pour la poursuite du projet.

mots-clés: nouveaux médias, journalisme, applications mobiles d'émission en directe, Periscope, Medyascope 


\section{Öz}

Yeni medya, haber üretim ve tüketim pratiklerini etkilemekte, geliştirilen yeni uygulamalar haber ekolojisinde değişime neden olabilecek yeni olanaklar sunmaktadır. Bu betimleyici çalışma, gazeteci Ruşen Çakır'ın, 7 Haziran 2015 tarihindeki genel seçimler öncesi mobil canlı yayın uygulaması Periscope platformu üzerinden gerçekleştirmeye başladığı yayıncılık deneyiminden hareketle ortaya çıkan Medyascope adlı çevrimiçi habercilik projesini konu almaktadır. Medyascope; canlı yayınların Periscope'un yanı sıra Facebook ve YouTube üzerinden de gerçekleştirilmesi, Skype bağlantısı ile yurt dışından da konukların yayına dâhil edilebilmesi, ani gelişen önemli toplumsal olaylarda farklı kullanıcıların Periscope yayınlarının derlenmesi gibi özellikleri barındırmaktadır. Bununla birlikte sosyal medyanın etkileşim özelliğinin az kullanılması ve uygun bir gelir modeli oluşturulamaması halinde ekonomik açıdan sürdürülebilirliği noktasında belirli sınırıııkları bulunmaktadır. Bu çalışmada, Medyascope ekibiyle derinlemesine görüşmeler ve 29 Ağustos-3 Eylül 2016 tarihleri arasında Periscope üzerinden gerçekleşen canlı yayınlara ait içerik analizi ile elde edilen veriler üzerinden Medyascope platformunun yapısı ve işleyişi ortaya konulmaya çalışıImış, çevrimiçi habercilik için önerilen gelir modellerinden hangilerine sahip olduğu ve bunların projenin geleceği açısından yeterli olup olmadığı gibi konuların tartışılması hedeflenmiştir.

anahtar kelimeler: yeni medya, habercilik, mobil canlı yayın uygulamaları, Periscope, Medyascope 


\section{Giriş}

Yeni medyanın temel özelliklerinden biri olarak gösterilen sayısallaşma (dijitalleşme) (Manovich, 2002) ile birlikte enformasyonun depolanması ve paylaşılması kolaylaşırken, profesyonel haber merkezlerindeki haber üretim süreci de analogdan dijitale doğru evrilmiş, mobil teknolojilerden daha fazla yararlanılmaya ve haber ekolojisindeki dönüşüm "video habercilik" ya da "mobil habercilik" gibi yeni kavramlarla ifade edilmeye başlanmıştır (Quinn, 2009). Sayısallaşma ile birlikte "bireylerin gördüklerine ve işittiklerine aktif olarak katılabilmelerine ya da biçimlendirebilmelerine olanak veren etkileşimli medya" gelişmiş (Giddens, 2008, s. 638), mobil cihazların ve internetin yoğun kullanımı sayesinde "daha önce sadece izleyici olarak bilinen insanların habercilik araç gereçlerini ve tekniklerini kullanarak" birbirlerine bilgi aktarması mümkün hale gelmiştir (Rosen, 2006). Böylece geleneksel medyanın "sessiz ve görünmez tüketicilerinin" sesini duyurabilmesine ve içerik üreterek farklı kanallardan dağıtabilmesine imkân tanınmış (Jenkins, 2006), "üreten-tüketici/tüketim" (produsage-produser) gibi yeni kavramlar ortaya atılmıştır (Bruns, 2008). Ayrıca bu dönemde "gazetecilik kimliği" nin de değiştiğini vurgulayan Saka (2012) ise yeni medya ile neyin haber olup neyin olmayacağına karar veren "uzmanlık paradigması"nın katılımcı kültür ile birlikte zayıfladığına dikkat çekmiştir.

Pavlik (2013, s. 11) ise yeni medya ortamında sunulan olanakların gazetecilere hikayelerini "eski analog medyada bulunan sınırlı yöntemlerle kısıtlanmaksızın anlatmalarını" sağladığını ifade etmektedir. Bu bağlamda sosyal medya ortamlarının da haberciler açısından birtakım sınırlııkları ortadan kaldırdığı söylenebilir. Örneğin Twitter, profesyonel haberciler için gündeme dair konularda ipuçları elde etme, haber kaynaklarıyla etkileşim sağlama ve ürettikleri haberin daha fazla sayıda insana ulaşabilmesi için duyuru yapma imkânı sunabilmektedir. Böylelikle sohbet, enformasyon paylaşımı gibi kullanımlarının yanı sıra haber üretimi ve dağıtımı açısından da dikkat çeken Twitter, habercilik alanını etkilemekte (Hermida, 2010) ve yurttaşların yanı sıra profesyonel haberciler ve haber merkezleri tarafından da yoğun şekilde kullanılmaktadır (Newman, 2009).

"Geleneksel medyanın televizyon yayıncılığına yeni bir rekabet alanı" olarak değerlendirilen yeni medya ortamlarındaki canlı yayın platformları ise "sermaye, kredi, patron, personel, teknik altyapı, ses, ışık, kamera" gibi unsurlar olmadan da canlı yayın yapılabilmesini mümkün kılması bakımından dikkat çekmektedir (Şahin, 2016). Bu uygulamalardan biri olan ve 2015 yılında Twitter'ın bünyesine kattığı Periscope, her an her yerden canlı görüntü aktarımı yoluyla haber üretim ve tüketiminde yeni bir deneyim alanı oluşturmuştur (Scott, 2015). İranlı girişimci Kayvon Beykpour, Periscope fikrinin 2013 Haziran ayında İstanbul'da bulunduğu dönemde başlayan Gezi eylemleri sırasında oluştuğunu ve o dönemde kendisine sorduğu "dünyada şu an neler olup bittiğini neden göremiyorum?" sorusuyla uygulamanın ilk tohumlarının atılığını ifade etmektedir (McCorvey, 2015). Bu fikri ortağı Joseph Bernstein ile San Francisco'da bir yazılım ekibi kurarak daha 
da geliştirdiklerini anlatan Beykpour, 2014 yılı Nisan ayında 1.5 milyon dolarlık yatırım aldıklarını belirtmektedir (Can, 2015). Bir yıl sonra 100 milyon dolarlık satışın ardından Twitter'ın bünyesine kattığı ve 26 Mart 2015 tarihi itibariyle kullanıcılarına tanıttığı Periscope uygulaması, ilk 10 günde 1 milyon kullanıcı sayısına ulaşmıştır (Wagner, 2015). Periscope, kendisinden önce hayata geçirilen benzer uygulamalar olan Livestream, Ustream ve Meerkat gibi örnekleri geride bırakmış ve "devrimsel" niteliği olduğu öne sürülerek Apple tarafından 2015 yılının en iyi uygulaması seçilmiştir (Warren, 2015).

Periscope uygulaması, bir süre sonra gelen güncelleme ile IOS işletim sisteminin yanı sıra Android işletim sistemine sahip cihazlar için de uygun hale getirilerek daha geniş bir kitlenin kullanımına sunulmuştur. Shaffer (2015), Twitter'ın satın almasının ardından Periscope uygulamasının Meerkat uygulamasından 10 kat popüler hale geldiğinin altını çizmektedir. Huston (2016) bu durumu, uygulamanın etkileşimli yapısına, kullanım kolaylığına ve saniyeler içinde canlı yayına geçme pratikliğini sunmasına bağlamaktadır. Dowell ve Duncan (2016) ise Periscope uygulamasını öne çıkaran unsurları, Twitter ile bütünleşik bir yapıda çalışması, kullanıcılara son 24 saatte yayınlanan videoları izleme imkânı sağlaması, yayıncılara yaptıkları yayınlar ile ilgili bazı sayısal veriler sunması, izleyicilerin beğenilerini gösterebilme olanağı vermesi şeklinde sıralamaktadır.

Dört ay içinde 10 milyon kullanıcı sayısına ulaşan Periscope uygulaması (Periscope by the numbers, 2015), farklı içerikte pek çok canlı yayının yapıldığı bir alana dönüşmüştür. "Sıradan" insanların sohbet etmek, fikir ve görüşlerini paylaşmak, eğlenmek; siyasilerin ve ünlülerin geniş kitlelere ulaşmak; ticari şirketlerin kendilerini ve ürünlerini tanıtmak vb. amaçlar için kullandığı Periscope uygulaması ile cinseliçerikli, argo, küfürve hakaretin bulunduğu ya da nefret söylemi barındıran ve özel yaşamın gizliliğinin ihlal edildiği yayınlar da yapılabilmektedir. Bu nedenle Periscope yayınlarının, "gözetimi mobilize, eşzamanlı ve aleni bir pratiğe dönüştürdüğü", "küresel ölçekte etkileşimli bir gözetim pratiğinin ortaya çıktığı" ve "mahremiyetin küresel ölçekte dolaşıma girmesine neden olduğu" ifade edilmektedir (Göker, 2016). Periscope aracılığıyla yapılan yayınlara ilişkin bir diğer tartışma ise telife konu yayınlar üzerine gerçekleşmektedir (Edelman, 2016). ABD'de özellikle yayın hakları satın alınan önemli spor karşılaşmalarının ve Game of Thrones gibi ilgi çeken dizilerin, yayıncı kuruluşun abonelerine ilettiği anda Periscope kullanıcıları tarafından da ücretsiz olarak yayınlanması, mobil canlı yayın uygulamalarının telif haklarının ihlal edildiği durumlarda nasıl bir yol izlemesi gerektiği üzerinde farklı görüşlerin ortaya atılmasına neden olmuştur (Reilly, 2015).

Bu uygulama ile birlikte pahalı uydu kirası, donanımlı araç ve teknik eleman gereksinimi nedeniyle geleneksel medyanın tekelinde görülen canlı yayın yapabilme olanağı, akıllı cep telefonu ve tablet gibi mobil cihaz ile internete erişimi bulunan her kullanııı için mümkün hale gelmiştir. Periscope uygulamasının özellikle profesyonel haberciler, haber merkezleri, yurttaş haberciler ve izleyiciler 
için "heyecan verici" bir yenilik sağladığını öne süren BBC sosyal medya editörü Mark Frankel (2015), canlı video akışının (live streaming) aslında yeni bir kavram olmadığını, ancak bu tür uygulamaların sosyal medya ile bütünleşmesinin önemli bir yenilik olduğunu belirtmektedir.

Periscope uygulaması habercilik bağlamında özellikle ani gelişen olayların gerçek zamanlı aktarıması ile dikkat çekmektedir (Rodriguez, 2015). Örneğin aralarında The Guardian'ın Washington muhabiri Paul Lewis'in (@PaulLewis) de bulunduğu bir grup gazeteci ABD'nin Maryland eyaletindeki Baltimore şehrinde çıkan olayları Periscope aracıı̆ı̆ılla canlı olarak aktarmış, bu durum "haberciliğin yeni bir çağı" olarak yorumlanmıştır. 25 Nisan 2015 tarihinde Nepal'de meydana gelen 7,8 büyüklüğündeki depremle ilgili daha çok cep telefonuyla habercilik yürüten BBC muhabiri Nick Garnett, (@nicholasgarnett) köylerdeki hasarı Persicope aracılığıyla canlı olarak aktarmıştır. Sky News muhabiri Mark Stone ise (@Stone_SkyNews) Katmandu'nun batısındaki bir hastaneden canlı yayın yapmıştır (Last Month in Periscope, 2015).

Türkiye'de de habercilerin Periscope ${ }^{1}$ uygulamasını farklı şekillerde kullandıkları görülmektedir. Bu betimleyici çalışmada, gazeteci Ruşen Çakır'ın, Periscope ile yaptığı canlı yayınların habercilik açısından yeni bir alan yaratabileceği fikrinden hareketle başta gazeteciler olmak üzere kolektif üretime açık bir haber/ yorum platformu olarak küçük bir ekiple hayata geçirdiği Medyascope örneği incelenmiştir. Çalışmanın temel amacı yeni medya ortamları üzerinden yürütülen bu habercilik ve yayıncılık girişiminin yapısını ve işleyişini inceleyerek, yayınların süresi, izleyici sayısı, etkileşim olanağı olup olmadığı gibi özelliklerini ortaya koymaktır. Ayrıca çalışmada çevrimiçi habercilik projelerinin temel sorunu olan ekonomik olarak sürdürülebilirliğin Medyascope projesinde ne şekilde sağlanmaya çalışıldığı sorusuna yanıt aranmaktadır. Bu amaç doğrultusunda Ruşen Çakır, Medyascope editörü Semih Sakallı ve Medyascope teknik koordinatörü Servet Dilber ile derinlemesine görüşmeler gerçekleştirilmiş, 29 Ağustos-3 Eylül 2016 tarihleri arasında Periscope üzerinden canlı olarak yayınlanan Medyascope programları içerik analizi tekniği ile incelenmiştir.

\section{Yıllık Gazetecinin Yeni Yayıncılık Deneyimi: Periscope}

Gazeteciliğe 1985 yılında başlayan Ruşen Çakır, mesleğinin otuzuncu yılında Marmara Üniversitesi Illetişim Fakültesi'nin açılış dersinde genç meslektaşlarına sosyal medyada muhakkak yer almalarını ve kişisel web sayfasının yanı sıra YouTube vb. ortamlarda kanal açarak görsel arşiv oluşturmalarını önermiştir. Gelen bir soru üzerine bir süredir kendisinin de kullandığı Periscope uygulamasına değinen Çakır, uygulamanın habercilik açısından bir fırsat olduğunu ancak bu durumun gençler tarafından henüz pek de fark edilmediğini ise şu sözlerle

1 Benzer isimli bir şirketin açtığı dava sonucunda Twitter, Türkiye'de Periscope olan uygulama adını Scope olarak değiştirdiğini duyurmuştur. Ancak çalışmanın genelinde uygulamanın küresel adı olan Periscope kullanılmıştır. 
aktarmıştır: "Periscope örneğini bir arkadaşım bana söyledi; baktım. 'Ben bile yapabilirim dedim bu yaşta'; çok kolay yani. Hayret ediyorum gençler bu mecrayı geyik muhabbeti dışındaki alanlarda niye kullanmıyorlar? Çok kolay, özellikle genç gazeteciler için çok elverişli bir şey" (Çakır, 2015a).

Ruşen Çakır, Türkiye'de meslektaşları arasında Periscope canlı yayınını ilk deneyimleyen isimlerden biri olmuştur. 7 Haziran 2015 genel seçimleri öncesi yapmaya başladığı yayınlar, Çakır'ın bu uygulama ile adının sıklıkla anılmasını sağlamıştır. Çakır, bu dönemde Periscope aracılığıyla Habertürk Gazetesi'ndeki ofisinden yaptığı yayınlarla seçime ilişkin analizlerini takipçilerine iletme fırsatı bulmuş, bunun yanı sıra Türkiye'nin farklı illerinde yerinde izlediği mitinglerden de canlı yayınlar yapmış, miting öncesi ve sonrasında yine Periscope üzerinden aralarında milletvekili adaylarının da bulunduğu çok sayıda kişiyle röportajlar gerçekleştirmiştir.

Fotoğraf 1. Ruşen Çakır'ın Habertürk Gazetesi'ndeki ofisinden Periscope aracılığıyla yaptığı seçim öncesi değerlendirmesine ilişkin canlı yayını (3 Haziran 2015)

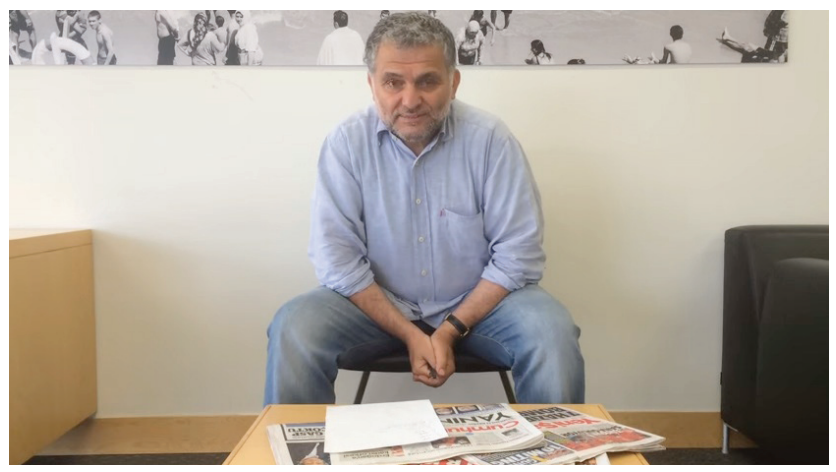

Katıldığı bir televizyon programında kendisinin uzun yıllardır mitingleri takip ettiğini belirten Çakır (2015c), son dönemde analiz ve yorum yapma imkânının kalmadığını ifade ederek Periscope uygulamasını bu bağlamda kendisi için önemli bir alan olarak değerlendirmektedir. Çakır, ilk Periscope canlı yayınını 19 Nisan 2015 tarihinde Ankara'da gerçekleştirmiştir. Illk denemesini CHP'nin grup toplantısı öncesinde yapan Çakır, hemen ardından gerçekleştirdiği ikinci Periscope yayınında CHP Genel Başkanı Kemal Kılıçaroğlu'nun grup toplantısından bir bölümü canlı olarak aktarır. Daha sonraki günlerde canlı yayınlarını İstanbul'da sürdüren Çakır, Habertürk Gazetesi'ndeki ofisinden 7 Haziran seçimlerine ilişkin analizlerini paylaşmıştır.

Çakır, seçim öncesi farklı illerde düzenlenen parti mitinglerine ilişkin yerinden izlenimlerini ve konuklarıyla söyleşilerini de Periscope üzerinden canlı olarak aktarmıştır. Ağırlıklı olarak iktidar partisine oranla medyada kendilerini 
daha fazla anlatma intiyacı duyan MHP, CHP ve HDP'li adaylarla konuştuğunu belirten Çakır (2015b), bu yayınların kendisi için olduğu kadar izleyiciler ve canlı yayına konuk ettiği kişiler için de farklı bir deneyim olduğunu ifade etmektedir. Konuştuğu adaylar arasında Periscope'tan haberi olan hemen hemen hiç kimse olmadığını ve çoğuna Periscope uygulamasını kendisinin tanıttığını söyleyen Çakır, yapacakları konuşmaların kaç kişiye ulaşacağını kestiremeyen konuklarının kendi ismine güvenmeleri nedeniyle röportajı kabul ettikleri görüşündedir.

Çakır (2015b), mitinglerde Periscope ile yaptığı bu canlı yayınların kimi meslektaşları tarafından da hafif küçümseme ve hatta dalga geçmeyle karşılansa da işini yapmaya devam ettiğini belirtmektedir. Türkiye'de gazeteci sayısına özellikle de işsiz gazeteci sayısına bakıldığında Periscope uygulamasının habercilik bağlamında kullanımının hâlâ çok geride olduğunu belirten Çakır'a göre uygulama "diyecek bir lafı olan" için önemli bir olanak sağlamaktadır:

\begin{abstract}
Bizim meslekte şikâyet çok yaygın bir şey. Insanlar şikâyet ediyor, haklılar da şikayet etmekte. Bir yerden sonra kimseye niye şikayet ediyorsun diyecek halimiz yok ama sonuç olarak eğer gerçekten bir şey yapmak istiyorsanız, bir cep telefonunuz varsa, ki herkesin var, internet bağlantıBirnız varsa, ki herkesin var insanın diyecek bir lafı varsa bunu kullanarak pekala diyebilir. (...) "Beni kim izler, kim dinler?" gibi şeyler olabiliyor. O da o zaman sizin diyeceğiniz lafla ilgili bir şey. Hakikaten ciddi bir şey söyleyecekseniz bunun alıcısı da muhakkak vardır. (Çakır, 2015b).
\end{abstract}

Seçim döneminde yaptığı Periscope yayınlarını daha sonra YouTube kanalına da yükleyen Çakır, bazı siyasi parti liderleriyle de Periscope söyleşileri gerçekleştirmiştir. Örneğin CHP Genel Başkanı Kemal Kılıçaroğlu, Trabzon mitingi sonrası parti otobüsünde halkı selamlarken bir yandan da Çakır'ın yönelttiği soruları cevaplamıştır. HDP Eş Genel Başkanı Selahattin Demirtaş ve Saadet Partisi Genel Başkanı Mustafa Kamalak ile de canlı yayın gerçekleştiren Çakır, MHP Genel Başkanı Devlet Bahçeli'ye de Yozgat mitingi sonrası benzer bir röportaj talebinde bulunduğunu, "Periscope uygulamasından haberi olmayan" Bahçeli'nin bu talebi, "Ben dibini görmediğim kuyudan su içmem." diyerek reddettiğini belirtmiştir (Çakır, 2015d).

\title{
Periscope Yayınlarından Doğan Bir Haber Platformu: Medyascope
}

20 Ağustos 2015 tarihinde Ruşen Çakır, Habertürk Gazetesi'ndeki ofisinde meslektaşları Levent Gültekin ve Kadri Gürsel ile birlikte Periscope üzerinden canlı olarak yayınlanan bir açık oturum yayını yapmıştır. Bu yayın aynı zamanda Medyascope projesinin de başlangıcını oluşturmuştur.

Medyascope fikrinin hayata geçirilmesinde ilk adım, ortak şirketleri bulunan ve yeni medya alanında çeşitli projeleri bulunan Denet Tezel ve Nurdan Üçer'in Ruşen Çakır'a gönderdikleri bir e-posta ile atılmıştır. Çakır'a yaptığı yayınları takip ettiklerini, bu konuyla ilgilendiklerini ve birtakım fikirleri olduğunu söyleyen 
Tezel ve Üçer, daha sonra Çakır'la yüz yüze gelerek neler yapabileceklerini görüşmüştür. Bu görüşmede Ruşen Çakır, kendisine ait Periscope yayınlarının paylaşıldığı bunun yanı sıra başka gazetecilerin de katkı sunabileceği bir platform oluşturmayı önermiş ve hazırlıklara başlanmıştır.

Çakır, yaptığı Periscope yayınlarına gösterilen ilginin ardından bu uygulamanın habercilik için "elverişli ve kullanışlı bir mecra olduğu" sonucuna vardığını belirterek, "başta gazeteciler olmak üzere, Periscope ve sosyal medyanın sunduğu diğer imkânları kullanan, kullanmak isteyenler için ortak bir mecra olmayı hedefleyen" Medyascope.tv'nin "gelecek katkılarla, video ağırlıklı, sivil, bağımsız, özgür ve çoğulcu haber/yorum platformu" olabileceğini ifade etmektedir (Medyascope Hakkında, 2015).

www.medyascope.tv web sitesi üzerinden yayınlarına başlayan Medyascope'un ilk dönemlerinde içeriğin zenginleştirilmesi için Ruşen Çakır yine kişisel çaba harcamış, kendisi gibi Periscope üzerinden yayın yapan Ünsal Ünlü2 ve Nevşin Mengü gibi meslektaşlarından yayınlarının Medyascope üzerinden de paylaşılması için izin istemiştir. Yine Çakır'ın ricasıyla Mete Sohtaoğlu dış politik konular üzerine yaptığı Periscope yorumlarıyla Medyascope platformunun gelişimine destek veren isimler arasında yer almıştır (Çakır, 2015b). Ruşen Çakır, kısa sürede içeriği zenginleşen ve adı duyulan Medyascope'un en büyük farkının video temelli yapısı olduğunu, tıpkı bir haber televizyonu gibi çalıştıklarını ve farklı içerikler üretmeye gayret ettiklerini belirtmektedir. "Dünyanın her yerinde bir televizyon ne yapabilirse hepsini yapmaya çalışıyoruz" diyen Çakır, kullandıkları içeriğin tamamının orijinal olmasının bir diğer önemli özellikleri olduğunu, kendi üretimleri dışında çeşitli Periscope yayınlarını paylaştıklarını, ancak bunun haricinde başka haber sitelerinden ya da televizyon yayınlarından içerik almadıklarını ifade etmektedir (Konall, 2016).

Eylül 2016 itibariyle www.medyascope.tv web sitesinde "Yayın Akışı", "Canlı Yayın", "Programlar", "Yazılar", "Podcast" ve "İçerik Sağlayanlar" başlıkları yer almaktadır. Medyascope.tv'ye içerik sağlayanlar arasında 120'nin üzerinde isim ile Doğruluk Payı platformu yer almaktadır. Bunlardan bir bölümü içerik üretmeye ya da hazırladıkları içerikleri paylaşmaya düzenli olarak devam ederken bir bölümünün katkısının düzensiz ve sayıca az olduğu görülmektedir. Medyascope.tv'de günlük, haftalık ya da on beş günde bir olarak yayınlanan ve siyaset, toplum, ekonomi, kültür ve spor kategorilerinde 21 program adı sıralanmaktadır (www.medyascope.tv, 2016).

2 Ünsal Ünlü, uzun yıllar gazete ve televizyon haber merkezlerinde görev almıştır. Şu an için herhangi bir medya kuruluşunda çalışmayan ve kendisini takip etmek isteyenlere Periscope aracılığıyla ulaşan Ünlü, uygulamayı en yoğun şekilde kullanan habercilerin başında yer almaktadır. Eylül 2015 tarihinden itibaren düzenli olarak hafta içi her sabah gündemi yorumlayan Ünlü, bu yayınları nedeniyle Çağdaş Gazeteciler Derneği'nin 2016 yılında verdiği Mahmut Tali Öngören Televizyon Programı Ödülü'ne değer bulunmuştur. 
Bu programların dışında gündeme ilişkin özel yayınların da sıklıkla yapıldığı görülmektedir. Stüdyoda gerçekleştirilen düzenli programların dışında Medyascope.tv'de üç farklı kategoride ele alınabilecek video içeriğinin de yer aldığı görülmektedir. Bunlardan ilki, haftalık olarak yayınlanan programlar içinden seçilerek kurgulanmış bölümlerin sunulduğu videolardır. Bunun haricinde kişisel hesaplarından Periscope yayını yapan kullanıcılardan derlenen içeriklere ilişkin videolar da paylaşılmaktadır. Gazetecilerin yaptığı Periscope yayınları daha sonra kendileri tarafından YouTube'a yüklenmekte, ardından Medyascope izleyicilerinin erişimine de sunulmaktadır. Ruşen Çakır (2015b), asında yaptıklarının içerik üreticileriyle bir tür işbirliği olduğunu söylemektedir.

Medyoscope.tv'de paylaşılan videolar arasında yer alan bir diğer önemli içerik ise farklı Periscope kullanıcılarının çoğunlukla gündeme ilişkin gerçekleştirdiği yayınlar arasından yapılan derlemelerdir. Sakallı (2015), çoğunlukla Denet Tezel'in, takip ettiği Periscope yayınları arasında önemli bulduklarını siteye eklediğini, kimi zaman da meydana gelen bir olayın olduğu yerde bölgesel arama yaparak olaya ilişkin Periscope yayınları bulup derlediğini aktarmaktadır.

Medyascope.tv'de en önemli ağırlığı videolar oluşturmakla birlikte yazılı ve sesli içerik üretimi de gerçekleştirilmektedir. Web sitesinde yer alan "Yazılar" kategorisinde, yabancı gazete, dergi ve web sitelerinden derlenen haber, makale ve röportajlar ile başta Ruşen Çakır olmak üzere çok sayıda gazeteci ve yazarın farklı konularda kaleme aldığı yazılar paylaşılmaktadır. Medyascope.tv'de gerçekleştirilen özel yayınlar, açık oturumlar ve programlara ait ses kayıtları ise "podcast" 3 olarak iTunes ve Soundcloud aracılığıyla kullanıcılara iletilmektedir. Özellikle genç kullanıcıların hareket halindeyken mobil internet kullanarak Periscope yayınlarını izlemeye maliyet açısından pek de yanaşmadığı fikrinden hareketle paylaşılan ses dosyaları, araç sürücülerine de seyir halindeyken yayını dinleme olanağı sağlamaktadır (Sakallı, 2015).

\section{Gazete Odasından Stüdyo Yayınına: Medyascope Platformunda Teknik Altyapı ve Yayıncılık Pratiği}

Ruşen Çakır'ın Habertürk Gazetesi'ndeki ofisinden yaptığı Periscope yayınlarında internet bağlantısı özellikle de ses kalitesi, başıca problemler olarak öne çıkmış, ofiste sadece gündüz saatlerinde yayın yapılması bir diğer sınırlıı̆ı oluşturmuştur. Ruşen Çakır (2015b), arkadaşı Manuel Çıtak'ın fotoğraf stüdyosunu Medyascope yayınları için kullanabileceklerini söylemesiyle yeni bir mekâna geçtiklerini ifade etmektedir. Stüdyo adım adım küçük bir televizyon stüdyosuna dönüştürülmüştür. Uygun ışıklandırma ile ses yalıtımı yapılan ve konukların ağırlanacağı bölüm perde ile kapatılan stüdyoda ses sorununun giderilmesi için

3 Podcast, internet üzerinden dağıtımı yapılan ses dosyalarını ifade eden bir terim olarak 2004 yııından itibaren kullanılmaktadır. Apple ürünü olan iPod'tan türetilen daha sonra yayınlara ait tüm ses kayıtlarının mp3 vb. formatlarda yayılması anlamında kullanılan podcast'in, kullanıcılara kolaylık ve taşınabilirlik anlamında pratiklik sağladığı ifade edilmektedir (Harvey, 2014). 
yaka mikrofonları satın alınmış, ilk dönemde kurulan wi-fi sistemi yetersiz kalınca uydu bağlantılı internet erişimine abone olunmuştur (Sakallı, 2015)

Medyascope yayınlarının ilk dönemlerinde Periscope canlı yayınları Ipad ile gerçekleştirilmekte, stüdyoda kurulan fotoğraf makinesinin video modu kullanılarak hem YouTube üzerinden de canlı yayın yapılmakta hem de daha sonra YouTube kanalına yüklenmek üzere yayınlar kaydedilmektedir. Böylece Periscope ya da YouTube üzerinden programları canlı yayınla izleyemeyenler için yayınları takip etme olanağı sağlanmaktadır. 4

Fotoğraf 2. İstanbul Levent'teki bir fotoğraf stüdyosu, Medyascope.tv yayın stüdyosuna dönüştürülmüştür.

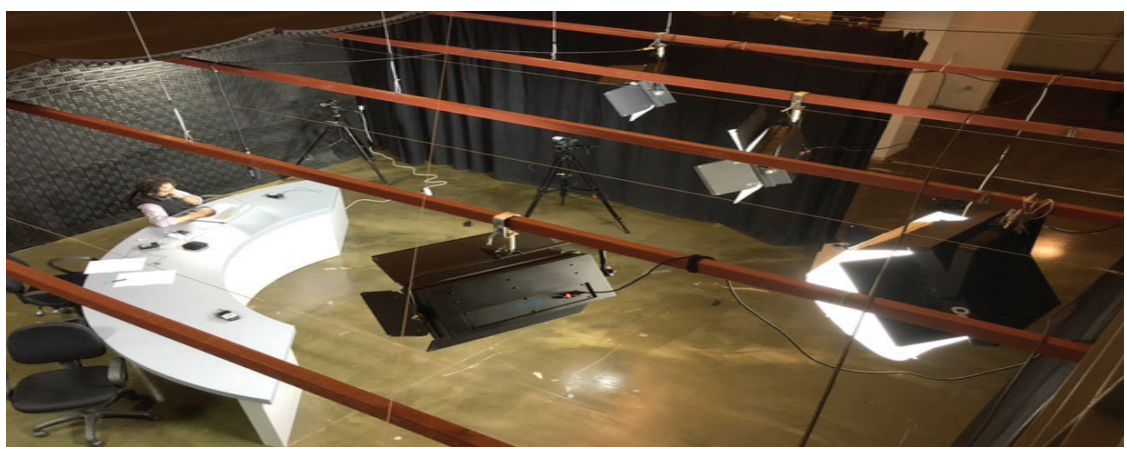

2016 yılı Şubat ayına kadar stüdyoda çekilen Medyascope programlarının en önemli teknik eksikliğinin tek kamerayla, tek açıdan çekim yapılması olduğunu belirten Sakallı (2015), bu durumun özellikle çok konuklu programları takip eden izleyici açısından da sıkıcı olabildiğini vurgulamaktadır. Söz konusu dönemde Periscope üzerinden yapılan canlı yayınlarda Medyascope programcılarının farklı teknik sorunlar yaşadığı ve kimi programcıların bu sorunları eğlenceli biçimde aşmaya çalıştığı da görülmüştür. Örneğin "Rominight" programının yapımcısı Romina Özipekçi televizyon programlarında olduğu gibi ara görüntüleri ekrana getirecek bir reji sistemine sahip olunmadığından yayın sırasında izletmek istediği görüntüyü önündeki bilgisayarı kameraya çevirerek izleyiciyle paylaşmıştır. Telefon bağlantısı sağlama cihazı (hibrit) olmaması nedeniyle konukların doğrudan cep telefonundan aranıp hoparlör üzerinden yayına alındığı programda, ekranda yer alması gereken isimler de kartona yazılmıştır. Romina Özipekçi, özellikle haber kanallarında sürekli görülen kayan altyazılara ise mekanik bir çözüm bulmuş, kâğıt ruloları masaya sabitlenen makaralarla çevirerek mizahi bir üslupla yayıncılığın farklı biçimlerde de gerçekleştirilebileceğinin örneklerini sunmuştur.

4 Facebook tarafından hizmete sunulan canlı yayın imkânı ile birlikte Medyascope yayınları Facebook kullanıcıları tarafından da canlı olarak izlenebilir hale gelmiştir. 
Fotoğraf 3. Medyascope.tv'nin ilk aylarında altyazı olanağı bulunmadığından bu soruna "Rominight" programının yapımcısı Romina Özipekçi'nin bulduğu eğlenceli çözüm (3 Ocak 2016)

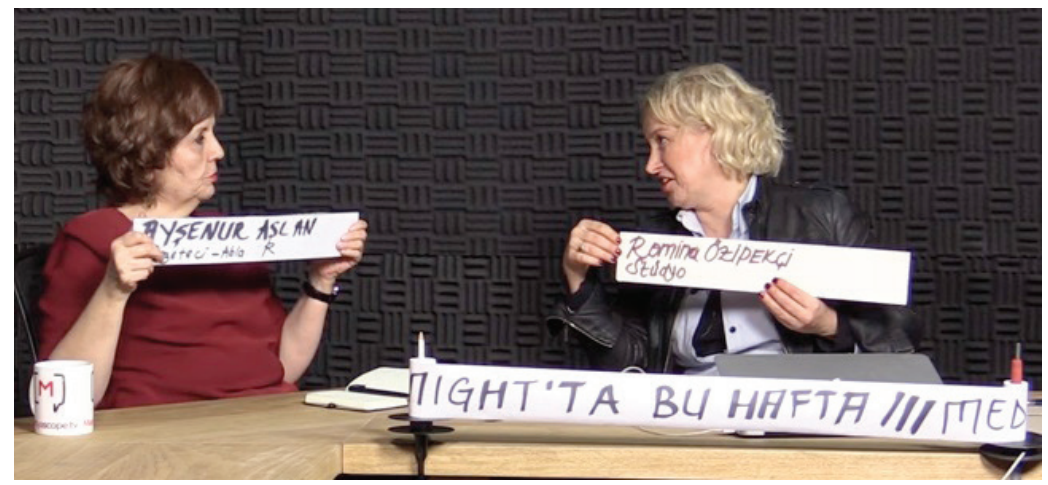

Şubat 2016 tarihinden sonra Medyascope.tv'de gerçekleştirilen canlı yayınlarda bu tür teknik sorunların büyük ölçüde giderilmeye başlandığı görülmüştür. Livestream canlı yayın yazılımı satın alınarak üç kamera ile resim seçimi mümkün hale gelmiş, ayrıca yayınlara grafik ve video eklenebilmiştir. Facebook ve YouTube üzerinden yapılan canlı yayınların linki medyascope.tv web sitesine de eklenmektedir. Periscope'un profesyonel yayın için hizmete sunduğu Periscope Producer ile de stüdyo yayını yüksek görüntü kalitesi ile Periscope yayınına aktarılabilmektir (Dilber, 2017). Stüdyo dışından konuklara Skype ya da canlı telefon bağlantısıyla ulaşımasını sağlayacak yayın altyapısı da sağlanarak Medyascope.tv'den yapılan yayınlara yurt dışı da dâhil olmak üzere farklı noktalardan katılım kolay hale gelmiştir.

\section{Medyascope Platformunun Ekonomik Yapısı ve İşleyiși}

Dijitalleşmenin yönlendirdiği yeni "haber ekolojisi"nde multimedya haberciliği, yurttaş haberciliği, katıımcı habercilik, çevrimiçi haber ve yayın siteleri gibi yeni iş ve üretim modelleri ortaya çıkmıştır. Örneğin BuzzFeed, Huffington Post, DNAInfo, Politico gibi çevrimiçi haber siteleri baskı maliyeti ya da yüksek idari bütçe gibi geleneksel medyanın ağır maliyeti olmadan haber üretebilmişlerdir. Ancak çevrimiçi haber sitelerinin mutlaka farklı platformlarda içerik üreterek hem bu alanlarda var olup daha fazla kişiye ulaşma hem de bu platformların kendisine özgü gelir modellerinden faydalanma yoluna gitmeleri gerektiği vurgulanmaktadır (Volkmer ve Firdaus, 2013, s. 101).

Çevrimiçi habercilik projelerinin ekonomik sürdürülebilirliği noktasında farklı ülkelerdeki deneyimleri ve iş modellerini inceleyen çalışmalarında Sirkkunen ve Cook (2012), reklam ve sponsorluk gelirleri, ücretli üyelik, bağış (kitlesel fonlama), etkinlik düzenleme, içerik üretme gibi yollarla gelir elde edilebileceğini 
ifade etmektedir. Kaye and Quinn (2010), habercilikte yeni iş modelleri üzerine yaptıkları araştırmada sponsorluk, fonlama ve bağışlar, ana akım medya (varlığınızı duyurarak daha fazla kişiye ulaşmanızı sağlamak için) ve yurttaş habercilerin katılımını sağlamak, içerik üretmek yoluyla gelir elde etmek, ortak bir amaç doğrultusunda çeşitli kurum ve kuruluşlarla işbirliği yapmak gibi önerileri sıralamaktadır. Ancak Kaye ve Quinn'e göre haber endüstrisi, ürünü kamu yararı sağlayan ender iş alanlarındandır ve izleyiciler ücretsiz ve erişimi kolay olduğu için çevrimiçi habercilik deneyimine yönelmektedirler. Dolayısıyla internetteki içeriğin ücretsiz olması gerektiğini düşünen izleyici kitlesi için ücretli üyelik dijital dönemin gelir kaynağı olmaktan uzaktır. ${ }^{5}$ Benzer şekilde eski yöntemlerle gelir elde etme çabasının zor olduğuna değinen Costa'ya göre de (2013, s. 63) "internet sitelerine geleneksel reklam almak yerine YouTube videolarının izlenme sayısının artırılmasıyla daha fazla gelir elde etmek" gibi yeni yöntemler üzerinde durulmalıdır, zira "çevrimiçi haberciliğin en büyük problemi, sadece yeni içerik üretme mücadelesi vermek değil, hayatta kalabilmektir".

Medyascope projesi, her ne kadar ilk döneminde para almadan çalışan yedi kişilik bir ekip ve çekim, kurgu, deşifre gibi teknik işlemleri yürüten gönüllü gençlerin katkısıyla yürütülmeye çalışılsa da (Sakallı, 2015) daha sonraki dönemlerde program sayısı ve süresinin artmaya başlaması ve buna bağlı olarak istihdam ve altyapının geliştirilmesi intiyacının öne çıkmasıyla birlikte gelir elde etme yöntemleri arayışı da önem kazanmıştır. Mart 2017 tarihi itibariyle kadrolu ve sigortalı şekilde 30'a yakın kişinin çalıştığını belirterek Scope Medya Ticaret ve Pazarlama A.Ş. bünyesinde faaliyet gösteren Medyascope'un ekonomik sürdürülebilirlik arayışına değinen Çakır (2017), reklamlarla gelir elde edebilmeyi umduklarını ancak bunun -sınırlı sayıdaki örnekler dışındahenüz istedikleri ölçüde gerçekleşmediğini belirtmektedir. Açık Toplum Vakfı, Chrest Foundation ve Heinrich Böll Stiftung'tan çeşitli projeler yoluyla destek aldıklarını belirten Çakır, maddi destek ya da cihaz alımı şeklinde gerçekleşen bu tür desteklerle altyapılarını güçlendirdiklerini, ancak bunların belirli süreler için geçerli gelir modelleri olduğunu ifade etmektedir. Nitekim çevrimiçi haberciliğin sürdürülebilirliği üzerine yapılan çalışmalarda da vakıf ve derneklerden elde edilen bu tür fonların sınırlı olduğu, habercilerin gelir elde edebilecekleri farklı yollar aradıkları vurgulanmaktadır (Funabiki ve Yoshihara, 2011). Giles (2010, s. 29) ise potansiyel fonlayıcıların olası amaçları göz önünde bulundurulduğunda, özellikle bağımsız habercilik projelerinin finansal destek arayışlarının çoğu kez gazetecilik etik ilkeleriyle çeliştiğinin altını çizmektedir.

5 Reuters Gazetecilik Çalışma Enstitüsü'nün 24 ülkeden 143 kişiyle görüşerek hazırladığı "Dijital Haber Projesi 2017" adlı raporda, dijital habercilik yapan kuruluş temsilcilerine 2017 yılında hangi finansal modele yönelecekleri sorulmuş, doğrudan okurlardan elde edilecek gelirin artırımasını hedefleyenlerin oranı, yüzde 47 ile ilk sırada yer almıştır. Diğer gelir modelleri ise reklam ya sponsorluk videoları ( yüzde 45), sponsor içerikleri (yüzde 40), gösterim bazlı reklam (yüzde 40), etkinlikler (yüzde 22), içerik-tanıım servisleri (yüzde 18), abonelik ve fonlama (yüzde 16) ve e-ticaret (yüzde 13) şeklinde sıralanmaktadır. 
Personel gideri dışında stüdyo kirası, elektrik, doğalgaz, internet, web sitesi gibi farklı giderleri bulunan Medyascope.tv'ye izleyici desteği sağlamak adına da çeşitli kitlesel fonlama projeleri de hayata geçirilmektedir. Bu amaç doğrultusunda www.patreon.com/medyascopetv adresi üzerinden izleyicilerin maddi katkı sağlayabileceği duyurulmuştur. Çakır (2017), kitlesel fonlama yoluyla elde edilecek gelir bakımından büyük beklentilerinin olmadıklarını belirtmiştir.

\section{Medyascope Yayınlarında Program İçerikleri ve İzleyici İlgisi}

29 Ağustos-3 Eylül 2016 tarihleri arasında Medyascope tarafından Periscope aracılığıyla canlı olarak 27 yayın yapılmıştır. Bu yayınlardan onu düzenli olarak devam eden şu programlardan oluşmaktadır: "FutBol Muhabbet", "Yan Yol", "Yakın Takip", "Zamanlama Manidar", "Bisiklet", "Eksik Olan", "Transatlantik", "Açık Oturum", "Kültür Sohbetleri".6 2 Eylül 2016 tarihinde yayınlanan iki program Medyascope fikrini geliştiren iki isim tarafından hazırlanıp sunulmuştur. Bunlardan ilki olan "Transatlantik"te Ruşen Çakır Skype bağlantısı ile Amerika Birleșik Devletleri'ndeki gelişmeleri ve Türkiye'deki toplumsal ve siyasal olayların ABD'de nasıl yorumlandığını her hafta orada bulunan Gönül Tol ve Ömer Taşpınar ile ele almaktadır. Sedat Pişirici'nin hazırlayıp sunduğu "Medyascope.tv Açık Oturumları" adlı programın ise 51 bölümü izleyici ile buluşmuştur.

Bu programların dışında Medyascope yayınlarında ağırlıklı olarak "Özel Yayın" başlıklı programların yer aldığı görülmektedir. Çalışma kapsamında incelenen 29 Ağustos-3 Eylül 2016 tarihleri arasındaki yayınların 14'ünün “Özel Yayın" adıyla gerçekleştirildiği tespit edilmiştir. Ağırlıkı olarak iç ve dış politik olaylar ve gündeme ilişkin toplumsal konuların ele alındığı bu özel yayınlara kimi zaman konuklar da davet edilmektedir. Özel yayınlardan dördü ise gazeteci Ruşen Çakır tarafından yapıımıştır. Çakır'ın hafta içi beş gün gerçekleştirdiği yayınlardan dördü "Özel Yayın" başlı̆ı̆ ile izleyiciye sunulmuştur.

Yayınlanan programlar süreleri bakımından incelendiğinde ortalama sürenin yaklaşık 32 dakika olduğu tespit edilmiştir. 29 Ağustos-3 Eylül tarihleri arasında yayınlanan programlardan "51. Medyascope.tv Açık Oturumu", 1 saat 12 dakika 56 saniye ile en uzun süreye sahip olan programdır. 31 Ağustos 2016 tarihinde Mete Sohtaoğlu'nun gerçekleştirdiği "IŞiD Sözcüsü Ebu Muhammed Adnani'nin Ölümü" başlıklı yayın 10 dakika 8 saniyelik süresiyle en kısa yayın olarak dikkat çekmektedir. Bu yayının bir diğer özelliği ise Mete Sohtaoğlu'nun yayını Medyascope stüdyosu yerine kendi Periscope hesabıyla evinden yapmış olmasıdır. Stüdyoda gerçekleștirilen programlar arasındaki en kısa süreli yayın (12:58) ise Elif Akbıyık'ın milli sporcu Büşra Ün ile yaptığı özel yayındır.

6 Medyascope.tv'nin program çeşitliliği daha sonraki dönemde artmıştır. Örneğin 17 Ekim 2016 tarihinde "Güne Bakış" adıyla hafta içi her gün saat 19.00'da gündeme dair konuları ele alan ana haber bülteni yayını başlamıştır. "Mor Saat", "Hayvan Gazetesi", "Şehir Hepimizin", "Teknoscope", "Kitapscope" da yeni eklenen programlar arasındadır. 
Tablo 1. 29 Ağustos-03 Eylül 2016 tarihleri arasında Medyascope.tv'nin Periscope aracılığıyla canlı olarak yayınladığı programlar

\begin{tabular}{|c|c|c|c|c|c|c|}
\hline $\begin{array}{l}\text { Tarih } \\
\text { Saat }\end{array}$ & Yayının Adı & Hazırlayan & Konuk & Süre & $\begin{array}{l}\text { Canlı } \\
\text { İzleyici }\end{array}$ & $\begin{array}{l}\text { Etkileşim } \\
\text { İmkanı }\end{array}$ \\
\hline $\begin{array}{l}29.08 .2016 \\
16: 00\end{array}$ & $\begin{array}{l}\text { Özel Yayın: IşiD } \\
\text { Neden Cerablus'ta } \\
\text { Savaşmadı? }\end{array}$ & Ruşen Çakır & - & 15:07 & 4397 & Kapalı \\
\hline $\begin{array}{l}29.08 .2016 \\
17: 00\end{array}$ & $\begin{array}{l}\text { Özel Yayın: Fırat } \\
\text { Kalkanı'nda Son } \\
\text { Durum }\end{array}$ & $\begin{array}{l}\text { Burak Tatari } \\
\text { Gökçe Çiçek } \\
\text { Kösedağı }\end{array}$ & Aydın Selcen & $37: 57$ & 3666 & Kapalı \\
\hline $\begin{array}{l}29.08 .2016 \\
18: 00\end{array}$ & $\begin{array}{l}\text { Özel Yayın: } \\
\text { Çocuklar İçin Barış } \\
\text { Girişimi }\end{array}$ & Recep Berber & $\begin{array}{l}\text { Alper Yalçın } \\
\text { Zeynep Kılıç }\end{array}$ & $25: 58$ & 1733 & Kapalı \\
\hline $\begin{array}{l}29.08 .2016 \\
20: 00\end{array}$ & $\begin{array}{l}\text { FutBOL } \\
\text { Muhabbet }\end{array}$ & $\begin{array}{l}\text { İlker Akgüngör } \\
\text { Müfit Gürevin }\end{array}$ & $\begin{array}{l}\text { Murat } \\
\text { Yücekök }\end{array}$ & 1:06:34 & 966 & Kapalı \\
\hline $\begin{array}{l}30.08 .2016 \\
14: 00\end{array}$ & $\begin{array}{l}\text { Özel Yayın: Melih } \\
\text { Şabanoğlu ile } \\
\text { Büyük Taarruz }\end{array}$ & $\begin{array}{l}\text { Burak Tatari } \\
\text { Gökçe Çiçek } \\
\text { Kösedağı }\end{array}$ & $\begin{array}{l}\text { Melih } \\
\text { Şabanoğlu }\end{array}$ & $31: 33$ & 758 & Kapalı \\
\hline $\begin{array}{l}30.08 .2016 \\
15: 00\end{array}$ & $\begin{array}{l}\text { Yan Yol: Kadın- } \\
\text { Erkek Eşitliği } \\
\text { Mümkün Mü? }\end{array}$ & $\begin{array}{l}\text { Irmak Bademli } \\
\text { Melis Oğuz }\end{array}$ & $\begin{array}{l}\text { Aylin } \\
\text { Yardımcı }\end{array}$ & $33: 53$ & 2545 & Kapalı \\
\hline $\begin{array}{l}30.08 .2016 \\
16: 00\end{array}$ & $\begin{array}{l}\text { Yakın Takip: } \\
\text { Menbiç'e Kara } \\
\text { Operasyonu } \\
\text { Olacak Mı? } \\
\end{array}$ & $\begin{array}{l}\text { Mete } \\
\text { Sohtaoğlu }\end{array}$ & - & $21: 25$ & 2241 & Açık \\
\hline $\begin{array}{l}30.08 .2016 \\
18: 30\end{array}$ & $\begin{array}{l}\text { Özel Yayın: } \\
\text { Cemaat } \\
\text { Operasyonlarının } \\
\text { Medya Ayağı } \\
\end{array}$ & Ruşen Çakır & - & $18: 03$ & 2691 & Kapalı \\
\hline $\begin{array}{l}30.08 .2016 \\
21: 00\end{array}$ & $\begin{array}{l}\text { Zamanlama } \\
\text { Manidar }\end{array}$ & \begin{tabular}{|l} 
Sadi Celil \\
Cengiz \\
\end{tabular} & Çetin Tankoç & $30: 31$ & 5844 & Kapalı \\
\hline $\begin{array}{l}31.08 .2016 \\
14: 00\end{array}$ & $\begin{array}{l}\text { Özel Yayın: } \\
\text { Türkiye'nin } \\
\text { Suriye'deki Varlı̆̆ı }\end{array}$ & $\begin{array}{l}\text { Burak Tatari } \\
\text { Gökçe Çiçek } \\
\text { Kösedağı } \\
\end{array}$ & Ünal Çeviköz & 33:08 & 2096 & Kapalı \\
\hline $\begin{array}{l}31.08 .2016 \\
15: 00\end{array}$ & $\begin{array}{l}\text { Özel Yayın Diğer } \\
\text { Cemaatlerin } \\
\text { "FETÖ"leşme } \\
\text { İhtimali }\end{array}$ & $\begin{array}{l}\text { Özgür } \\
\text { Özdemir }\end{array}$ & $\begin{array}{l}\text { Ömer Faruk } \\
\text { Gergerlioğlu }\end{array}$ & $21: 59$ & 679 & Kapalı \\
\hline $\begin{array}{l}31.08 .2016 \\
15: 30\end{array}$ & $\begin{array}{l}\text { IŞID sözcüsü } \\
\text { Ebu Muhammed } \\
\text { Adnani'nin ölümü }\end{array}$ & $\begin{array}{l}\text { Mete } \\
\text { Sohtaoğlu }\end{array}$ & - & 10:08 & 408 & Açık \\
\hline $\begin{array}{l}31.08 .2016 \\
16: 00\end{array}$ & $\begin{array}{l}\text { Özel Yayın: Rio } \\
\text { Parilimpik Oyunları }\end{array}$ & Elif Akbıyık & Büşra Ün & $12: 58$ & 1045 & Kapalı \\
\hline
\end{tabular}




\begin{tabular}{|c|c|c|c|c|c|c|}
\hline $\begin{array}{l}31.08 .2016 \\
18: 00\end{array}$ & $\begin{array}{l}\text { Özel Yayın: Barış } \\
\text { Çağrısı Karşılık } \\
\text { Bulur mu? }\end{array}$ & Oral Orpak & $\begin{array}{l}\text { Hakan } \\
\text { Tahmaz }\end{array}$ & $49: 30$ & 2759 & Kapalı \\
\hline $\begin{array}{l}31.08 .2016 \\
21: 00\end{array}$ & $\begin{array}{l}\text { Özel Yayın: Öcalan } \\
\text { Sorunu }\end{array}$ & Ruşen Çakır & - & $19: 59$ & 3303 & Kapalı \\
\hline $\begin{array}{l}31.08 .2016 \\
21: 30\end{array}$ & Bisiklet & Gürsel Akay & $\begin{array}{l}\text { Murat } \\
\text { Suyabatmaz }\end{array}$ & $35: 14$ & 1100 & Kapalı \\
\hline $\begin{array}{l}01.09 .2016 \\
13: 00\end{array}$ & $\begin{array}{l}\text { Özel Yayın Efkan } \\
\text { Ala Neden İstifa } \\
\text { Etti? }\end{array}$ & Firat Fistık & Erdem Gül & $15: 59$ & 4431 & Kapalı \\
\hline $\begin{array}{l}01.09 .2016 \\
15: 00\end{array}$ & $\begin{array}{l}\text { Özel Yayın: İslam, } \\
\text { İslamcılık ve } \\
\text { Cemaatler }\end{array}$ & Ruşen Çakır & - & $46: 28$ & 6189 & Açık \\
\hline $\begin{array}{l}01.09 .2016 \\
18: 00\end{array}$ & $\begin{array}{l}\text { Özel Yayın Vedat } \\
\text { Türkali'nin Ardından }\end{array}$ & $\begin{array}{l}\text { Burak Tatari } \\
\text { Gökçe Çiçek } \\
\text { Kösedağı }\end{array}$ & $\begin{array}{l}\text { Telefon } \\
\text { Bağlantıları }\end{array}$ & $34: 21$ & 2387 & Kapalı \\
\hline $\begin{array}{l}01.09 .2016 \\
21: 00\end{array}$ & $\begin{array}{l}\text { Özel Yayın Nadir } \\
\text { Devlet ile İslam } \\
\text { Kerimov ve Orta } \\
\text { Asya'daki } \\
\text { değişimler }\end{array}$ & $\begin{array}{l}\text { Burak Tatari } \\
\text { Gökçe Çiçek } \\
\text { Kösedağı }\end{array}$ & Nadir Devlet & $28: 52$ & 702 & Kapalı \\
\hline $\begin{array}{l}02.09 .2016 \\
15: 00\end{array}$ & Eğitimpedia & $\begin{array}{l}\text { Ali Koç, Müjdat } \\
\text { Ataman, Yılmaz } \\
\text { Erdal }\end{array}$ & - & 45:01 & 2310 & Kapalı \\
\hline $\begin{array}{l}02.09 .2016 \\
16: 00\end{array}$ & $\begin{array}{l}\text { Yakın Takip : } \\
\text { Cerablus Sonrası } \\
\text { El-Bab Yarışı }\end{array}$ & $\begin{array}{l}\text { Mete } \\
\text { Sohtaoğlu }\end{array}$ & - & $17: 52$ & 1560 & Açık \\
\hline $\begin{array}{l}02.09 .2016 \\
17: 00\end{array}$ & Eksik Olan & Erhan Dalkıran & $\begin{array}{l}\text { Alp } \\
\text { Kozanoğlu }\end{array}$ & $33: 54$ & 431 & Kapalı \\
\hline $\begin{array}{l}02.09 .2016 \\
18: 00\end{array}$ & $\begin{array}{l}\text { Transatlantik: } \\
\text { Cerablus } \\
\text { operasyonu, } \\
\text { Clinton-Trump } \\
\text { yarışı }\end{array}$ & Ruşen Çakır & $\begin{array}{l}\text { Gönül Tol } \\
\text { Ömer } \\
\text { Taşpınar }\end{array}$ & $29: 38$ & 2179 & Kapalı \\
\hline $\begin{array}{l}02.09 .2016 \\
21: 00\end{array}$ & $\begin{array}{l}\text { 51. Medyascope.tv } \\
\text { Açık Oturumu }\end{array}$ & Sedat Pişirici & $\begin{array}{l}\text { Mustafa } \\
\text { Aydın } \\
\text { Amberin } \\
\text { Zaman }\end{array}$ & $1: 12: 56$ & 3270 & Kapalı \\
\hline $\begin{array}{l}03.09 .2016 \\
12: 00\end{array}$ & $\begin{array}{l}\text { Kültür Sohbetleri: } \\
\text { Bir İsyanın 600. Yılı } \\
\text { Simavnalı Bedrettin }\end{array}$ & $\begin{array}{l}\text { Cengiz } \\
\text { Özdemir } \\
\text { Ozan Sağsöz }\end{array}$ & Nurdan Arca & 53:11 & 4077 & Kapalı \\
\hline
\end{tabular}

Periscope aracılığıyla gerçekleştirilen canlı yayınlar arasında izleyicinin en fazla ilgi gösterdiği programlar "Zamanlama Manidar" (5844 canlı izleyici), "Kültür Sohbetleri" (4077 canlı izleyici) ve "Medyascope.tv Açık Oturumu" (3270 canlı izleyici) şeklinde sıralanmaktadır. Bu programlar dışında "Özel Yayın” başlığıyla yapılan canlı yayınlardan Burak Tatari ve Gökçe Çiçek Kösedağı'nın 29 Ağustos 
tarihinde yaptığı yayını 3666, 1 Eylül'de gerçekleştirdikleri yayını ise 2787 canlı izleyici takip etmiştir. Ancak bu özel yayınlardan özellikle Ruşen Çakır'ın yaptığı Periscope yayınlarının daha fazla ilgi çektiği görülmüştür. Çakır'ın özel yayınları 29 Ağustos'ta 4397, 31 Ağustos'ta 3303 ve 1 Eylül'de ise 6189 canlı izleyici ile buluşmuştur.

Tablo 2. 29 Ağustos-03 Eylül 2016 tarihleri arasında Medyascope.tv'de en fazla canlı izleyici sayısına sahip programlar

\begin{tabular}{|l|l|l|l|}
\hline Programın Adı & Yayın Tarihi & Yayın Platformu & Toplam Canlı İzleyici \\
\hline R. Çakır Özel Yayın & 1 Eylül 2016 & Periscope & 6189 \\
\hline Zamanlama Manidar & 30 Ağustos 2016 & Periscope & 5844 \\
\hline R. Çakır Özel Yayın & 29 Ağustos 2016 & Periscope & 4397 \\
\hline Kültür Sohbetleri & 3 Eylül 2016 & Periscope & 4077 \\
\hline
\end{tabular}

Bu programları ve özel yayınları kaç izleyicinin canlı olarak izlediği, yayının bitiminin ardından yayın yapan kullanıcının Periscope hesabından görülebilmektedir. Ancak bu toplam sayı, canlı yayın sırasında kısa süreli yayına dâhil olup sonra ayrılan Periscope kullanıcılarını da içermektedir. Dolayısıyla Medyascope.tv'ye yönelik izleyici ilgisini net olarak bu sayılarla ortaya koymak belirli sınırlıklar içermektedir. Ayrıca canlı yayının tekrarı (eğer yayın kaydı silinmemişse) yayın bittikten sonra yayıncının Periscope hesabı ${ }^{7}$ üzerinden izlenebilmektedir. Hem yeniden izlenme sayısı hem de programların YouTube ve Facebook aracılığıyla da canlı olarak yayınlandığı ve kayıtların daha sonra YouTube'a yüklenip buradan da izlenebildiği düşünüldügünnde toplam izleyici sayısının daha da artacağı öngörülebilir. Nitekim “Medyascope web sitesinin aylık ortalama izleyici sayısının 130 bin olduğu; Periscope ve YouTube gösterimlerinin de eklenmesiyle bu sayının 250-300 bine çıktığı" öne sürülmektedir (Kara, 2016).

15 Temmuz darbe girişiminin ardından Medyascope.tv'de Ruşen Çakır, pek çok kişinin görüşlerini merak ettiği Bülent Arınç'ı televizyon ekranlarından önce Medyascope yayınına konuk almış, ertesi gün ana akım medyada bu yayından hareketle haberler yapılmıştır. 8 Bu yayını sadece Periscope uygulamasından canlı

7 Aralık 2015 tarihine kadar daha fazla takipçiye ulaşması amacıyla tamamıla Ruşen Çakır'ın Periscope hesabı üzerinden yapılan Medyascope canlı yayınları, bu tarihten itibaren isteğe bağlı şekilde programcıların kendilerine ait Periscope hesabından da yapılmıştır (Sakallı, 2015). Ancak Periscope Producer kullanılmaya başlandıktan sonra Periscope canlı yayınları sadece Medyascope hesabıyle gerçekleştirilmeye başlanmıştır (Dilber, 2017).

8 Darbe girişiminin ardından www.medyscope.tv'ye erişim, 17 Temmuz 2016 tarihinde bazı haber siteleri ile birlikte engellenmiştir. Medyascope Twitter hesabından "Maalesef TiB sitemize erişimi engelledi. Gerekçeyi bilmiyoruz. Hemen itiraz edeceğiz." mesajı takipçilere iletilmiş, Ruşen Çakır da yine Twitter'dan VPN kullanılması yönünde çağrıda bulunmuştur (Türkiye'de bazı haber sitelerine erişim engeli, 2016). Aynı günün akşam saatlerinde web sitesi yeniden erişime açılmıştır. 
olarak izleyenlerin sayısı 31 bini geçmiştir. Çakır'ın, "Sekiz Soruda 15 Temmuz Darbe Girişimi" başlıklı yayını 12.603 canlı izleyici sayısına ulaşmış, 10 Eylül 2016 tarihi itibariyle 22.910 kişi ise Periscope aracılığıyla yayının tekrarını izlemiştir. Çakır'ın bu dönemde konuk aldığı Hanefi Avcı ile yaptığı yayınsa 11.628 canlı izleyici tarafından takip edilmiştir. Çakır (2015b), haber ve yoruma daha fazla intiyaç duyulan önemli toplumsal ve siyasal gelişmelerin ardından Medyascope platformuna olan ilginin arttığını ifade etmektedir.

Medyascope'un ana akım medyada sıklıkla ekrana çıkma fırsatı bulamayan gazeteci, siyasetçi ve akademisyenlerin izleyici ile buluştuğu bir mecra olduğu söylenebilir. Bunun yanı sıra ana akım medyada sıklıkla tartışımayan kent ve kentlilik bilinci, insan hakları, hayvan hakları vb. konularda da programlar yapılmaktadır. Ancak Çakır, yaptıkları işi tanımlarken "muhalif, alternatif olma gibi çok kullanılan kavramları, sıfatları kullanmak istemediklerini, bundan hoşlanmadıklarını" ifade etmekte, "aktivist" değil "gazeteci" olduklarının altını çizmektedir. Çakır'a göre Medyascope, "haberin ve yorumun özgür bir şekilde dolaşabileceği video ağırlıklı, görsellik ağırlıklı bir yayıncııı" anlayışından ibarettir (Öktemer, 2015). Çakır (2015b) ayrıca Medyascope fikrini, Türkiye'de basın özgürlüğü sorunu ile ilişkilendirerek yorumlamanın doğru olmadığı, bunu geleneksel medyanın dijitale dönüşümünün bir sonucu olarak değerlendirmek gerektiği görüşündedir.

Çakır, bir başka röportajında da Medyascope projesiyle muhalif ya da alternatif değil, ana akım medya olmak, herkese ulaşmak ve "evrensel habercilik ilkelerine dayanan bir gazetecilik" üretimi gerçekleştirmek isteğini yinelemiştir (Tunç, 2016).

Bir bisiklet programını herhangi bir medya üzerinde göremezsiniz. Bisiklet programını biz burada aylardır yapıyoruz, az da olsa belli bir izleyici kitlesi var. En çok ilgiyi siyasi şeyler görüyor. Bizim şöyle bir derdimiz var; biz ana akım medya kurumu olmak istiyoruz. Kendimizi belli bir yere sınırlamak istemiyoruz. Dolayısıyla habercilik reflekslerimiz daha serinkanlı ve herkesin izleyebileceği bir medya yaratmak istiyoruz (Konalı, 2016).

Ruşen Çakır'ın Medyascope projesi ile gösterdiği yeni teknolojileri kullanarak bağımsız gazetecilik yapma çabası, ilk yılını doldurmadan önemli bir başarı da elde etmiş, Uluslararası Basın Enstitüsü (IPI International) tarafından "2016 Free Media Pioneer Award" ile ödüllendirilmiştir. IPI Yönetici Direktörü Barbara Trionfi, "Medyascope, aralarında hükümet baskısı nedeniyle işlerini kaybedenlerin de olduğu gazetecilere geniş kitlelere ulaşabilecekleri, sansürsüz, bağımsız habercilik için yeni bir platform sunuyor. Diğer ülkelere de örnek olabilecek bir model oluşturuyor" ifadesiyle ödülün gerekçesini ortaya koymuştur (IPI 2016 Free Media Pioneer Ödülü Medyascope'a, 2016). 


\section{İzleyici Etkileşimi Bağlamında Medyascope Yayınları}

Geleneksel medya pasif tüketimi beraberinde getirirken etkileşim, yeni medyaya değer katan anahtar unsurlardan biri olarak işaret edilmekte ve kullanıcının medya içeriğine dâhil olmasının önemi vurgulanmaktadır (Lister vd., 2009 , s. 21). Yeni medyanın öne çıkan etkileşim özelliği Periscope uygulamasında da görülmekte, izleyiciler gönderdikleri "kalplerle" yayını beğendiklerini ifade etmektedir. Periscope'un kurucusu Beykpour'a göre bu durum, uygulamayı benzerlerine göre çok daha samimi bir yapıya büründürmektedir (McCorvey, 2015). Bunun yanı sıra izleyiciler, soru ve yorumlarını da yayını yapan kişiye ulaştırabilmektedirler. Yayıncı dilerse yayınına gelen yorumları sadece kendisinin takip ettiği kullanıcılardan gelecek şekilde sınırlayabilmekte ve yorumundan rahatsız olduğu bir kullanıcının yayına erişimini engelleyebilmektedir.

Ruşen Çakır'ın 7 Haziran seçimleri öncesinde kişisel Periscope hesabı üzerinden yaptığı canlı yayınlara da bu anlamda çok sayıda beğeni, soru ve yorum gelmiş, ancak yorumlardan bazılarının kimi zaman hakarete kimi zaman da küfür ve tehdide dönüştügü görülmüştür. Bunun üzerine bu tür yorum yapan kullanıcılar engellenmiş ve bazı yayınlar yoruma kapalı olacak şekilde gerçekleştirilmiştir (Sakallı, 2015).

29 Ağustos-3 Eylül 2016 tarihleri arasında gerçekleştirilen Medyascope canlı yayınlarından sadece dördü tüm izleyici yorumlarına açık olacak şekilde sürdürülmüştür. Dolayısıyla Medyascope tarafından yapılan Periscope yayınlarının büyük çoğunluğunda izleyicilerin tamamının yorum yapabileceği bir etkileşim imkânı bulunmamaktadır. Tüm yorumlara açık olan dört yayından üçü Mete Sohtaoğlu'nun canlı Periscope yayınlarından oluşmaktadır. Ancak yayıncı tarafından bu yorumlar dikkate alınmadığından, burada da herhangi bir yayıncıizleyici etkileşimi bulunmamaktadır.

Bu bağlamda incelemenin yapıldığı dönemdeki tek istisna, 1 Eylül 2016 tarihinde gerçekleştirilen ve Ruşen Çakır'ın "İslam, İslamcılık ve Cemaatler" konusunu ele aldığı özel yayındır. Ruşen Çakır (2015b) kendi yaptığı yayınlarda yorumun sınırlandırılmış olmasının küfür, hakaret vb. nedenler dışında süre ile de ilgili olduğunun altını çizmiş, tartışılan konu ve stüdyo konuğuna kendi yönelteceği sorularla zaten programın süresinin dolduğunu ve bu nedenle izleyici sorularına zaman kalmayacağı için yorum ve soru alınmadığını belirtmiştir. Ancak Çakır'ın yaptığı diğer yayınların aksine, bu özel yayında izleyicilerin tamamına yayına kullanıcı yorumu ekleyebilme imkânı tanınmış, reji ekibi gelen sorulardan bazılarını seçerek ekrana aktarmış ve Çakır bu soruları doğrultusunda yayını sürdürmüştür.

Periscope üzerinden 6189 canlı izleyiciye ulaşan bu özel yayına toplam 112 soru ve 216 yorum gelmiş, 51 kullanıcı ise uygunsuz içerik nedeniyle engellenmiştir. Aslında her ne kadar yoruma açık yayınlar, küfür, hakaret vb. yorumlar içermesi ve bu yorumları yapan kullanıcıların engellenmesinin yayın 
ekibine ilave bir yük getirmesi bakımından belirli risk ve zorluk barındırsa da, incelenen dönemde en fazla ilgi gören yayının, yoruma açık olarak yapılan yayın olması, Medyascope platformunun yayıncılık anlayışında etkileşimli yapının daha da geliştirilmesinin önemini göstermektedir. Nitekim söz konusu yayının son bölümlerinde Ruşen Çakır da "Maalesef bizim kullandığımız Periscope başta olmak üzere sosyal medyayı kötü niyetli kullanan insanlar çok olduğu için ve iyi niyetle kullanan izleyicilerimizi, takipçilerimizi rahatsız etmemek için yoruma kapalı yapıyoruz genellikle, ama olabildiğince bunu kırmaya, daha açmaya çalışacağız." diyerek yoruma ve açık sayısını artırmayı ve Medyascope'u daha etkileşimli hale getirmeyi istediklerini ifade etmiştir.

\section{Sonuç}

Yeni medya, internetten dijital oyunlara, sosyal medyadan cep telefonları ve ağ dolayımlı diğer iletişim ortamlarına kadar geniş bir alanı ifade eden bir kavram olarak ele alınmakta ve "siyasal, toplumsal, kültürel, ekonomik ve psikolojik yansıları sosyal ve beşeri bilimlerin gündemini" etkilemesi nedeniyle pek çok akademik çalışmanın konusu haline gelmektedir (Binark, 2015, s. 9-13). Geleneksel medyanın ve medya endüstrisinin içinde bulunduğu koşullar, değişen medya tüketim pratikleri vb. nedenlerin yanı sıra yeni medyanın haber ekolojisinde de değişim ve dönüşümlerin yaşanmasına sebep olduğu görülmektedir.

Yeni medyanın sunduğu olanaklar ile geleneksel medyanın yayınclık açısından tekel olma hali pek çok açından kırılmış, yeni medya dolayımlı iletişim ile farklı yayınclık modellerine kitlelerin erişimi kolaylaşmıştır. Bloglar, kişisel web siteleri ile başlayan kullanıcının haber üretimine katılımı, sosyal medya ağları ile daha da yaygınlık kazanmıştır. Mobil canlı yayın platformları ile birlikte geleneksel medyanın kendine has özelliklerinden sayılan ve yüksek maliyeti ile "sıradan" kullanııının erişmesi hayal dahi edilemeyen canlı yayın olanağı dahi -kısıtlı bir kitlenin ulaşabildiği bir sınırlılıkla da olsa- herkesin yapabileceği bir etkinlik halini alabilmiştir.

Bu platformlardan biri olan Periscope'un canlı yayın olanağı farklı biçimlerde kullanılmakta, bireylerin sohbet, eğlence vb. amaçlarla yaptıkları yayınların yanı sıra gündelik hayatlarından anları paylaştıkları, içerisinde yer aldıkları etkinlikleri canı olarak yayınladıkları da görülmektedir. Ancak bunun dışında Periscope uygulaması ile cinsel içerikli, nefret söylemi barındıran, özel hayatın gizliliğinin ya da telif haklarının ihlal edildiği canlı yayınlara da sıklıkla rastlanabilmektedir. Bu türden kullanım alanları, yaşanan etik ihlaller ile diğer olanak ve sınıllıklarının kapsam dışında tutulduğu bu betimleyici çalışmada Periscope uygulamasının özellikle gazetecilik ve yayıncılık açısından ne tür fırsatlar sunabileceği Medyascope örneği üzerinden değerlendirilmiştir. 
Kolektif bir üretimin sağlama hedefiyle oluşturulan Medyascope'ta üretilen programlar, Periscope, Facebook ve Youtube üzerinden canlı olarak yayınlanmaktadır. Ancak bu tür canlı yayınların en önemli ortak özelliği olarak nitelendirilebilecek yayıncı-izleyici etkileşimi, Medyascope yayınlarında görülmemektedir. Küfür, hakaret vb. içerikler nedeniyle yayınlar çoğunlukla yoruma kapalı şekilde gerçekleştirilmekte, sosyal medya platformları sadece canlı yayın özellikleri açısından kullanılmaktadır.

Medyascope projesinin en önemli özelliğinin, habercilerin yeni medyanın olanaklarını kullanarak izleyicilerine ulaşma arayışına bir alternatif sunması olduğu söylenebilir. Bunun dışında Medyascope, ana akım medyada yer bulamayan kişilerin ve sıklıkla ele alınmayan konuların kamuoyuyla buluşturulması bakımından da ana akıma alternatif bir model olarak değerlendirilebilir. Ancak Ruşen Çakır, bu noktada Medyascope'un muhalif ya da aktivist medya olarak nitelendirilmesine karşı çıkmakta, kendilerinin gelir elde etmeye çalışan bir ana akım medya kuruluşundan veya bir haber kanalından farklılıklarının bulunmadığını vurgulamaktadır.

Internet ortamlarında yürütülen habercilik projelerinin sürdürülebilir bir gelir modeli oluşturamaması pek çok çalışmada temel sorun olarak görülmekte ve reklam, sponsorluk, kitlesel fonlama, vakıf ve derneklerden bağış, içerik üretme, ücretli üyelik gibi yöntemlerin yanı sıra yeni ve alternatif gelir modellerinin üretilmesinin bir zorunluluk haline gelebileceği aksi takdirde çevrimiçi habercilik projelerinin geleceğinin ekonomik anlamda karanlık hale gelebileceği ifade edilmektedir (Kaye and Quinn, 2010; Sirkkunen ve Cook, 2012; Costa, 2013). Üstelik sadece bağımsız çevrimiçi habercilik projeleri değil farklı ülkelerdeki medya kuruluşlarının yeni medya birim temsilcilerinin de özellikle dijital reklamla finansal sürdürülebilirliğin daha zor hale gelmesinden yakındıkları ve yeni iş modellerine yöneldikleri görülmektedir (Newman, 2017). Pavlik (2013, s. 234) ise çevrimiçi haberciliğin geleceğinin, başarılı iş modeli ve kaliteli haber içeriği geliştirilmesinde saklı olduğunu, kâr elde edebilmeninse uzun yıllar alabileceğini belirtmektedir.

Dolayısıyla çevrimiçi ortamda yürütülmeye çalışılan habercilik projelerinin yaşadığı bu tür zorluklar Medyascope açısından da önemli bir problem olarak görünmektedir. Kuruluşundan itibaren hedeflenen reklam gelirine ulaşamayan Medyascope, çeşitli vakıflardan maddi destek sağlayarak özellikle altyapısını güçlendirmeye çalışmıştır. Bunun dışında kitlesel fonlama yoluyla izleyicilerden katkı sağlanmasına yönelik adımlar da atılmaktadır. Ancak bu süreli ve sınırlı kaynakların, düzenli yayın yapmaya ve özgün içerik üretmeye çalışan Medyascope'un gelişimine ne oranda katkı sağlayacağı sorusundan hareketle, alternatif gelir modellerinin kısa sürede oluşturulmasının Medyascope projesinin geleceği açısından hayati olduğu ifade edilebilir. 


\section{Kaynakça}

Binark, M. (2015). “Yeni Medya Çalışmaları Özel Sayısı Hakkında? Neden? Folklor/ Edebiyat, 21(83), 9-18.

Bruns, A. (2008). Blogs, Wikipedia, Second Life and Beyond: From Production To Produsage. New York: Peter Lang.

Can, A. (28 Mart 2015). Gezi'den Milyonluk Fikir Çıktı. Hürriyet Gazetesi. Erişim 16 Nisan 2015, http://www.hurriyet.com.tr/ekonomi/28578596.asp

Costa, C. T. (2013). A Business Model for Digital Journalism: How Newspapers should Embrace Technology, Social and Value Added Services. Columbia University Graduate School of Journalism Report. Erişim 3 Mart 2017, https:// drive.google.com/file/d/0B7GX5q7T2OK2cmIFMFhwNVpqR3c/view

Çakır, R. (2015a). Medyanın Çağımıza Cevap Verebilmesi İçin Neler Yapabiliriz? Erişim 14 Ekim 2015, http://medyascope.tv/2015/09/14/medyanin-cagimizacevap-verebilmesi-icin-neler-yapabiliriz-marmara-universitesi-iletisim-fakultesiacilis-dersi

Çakır, R. (2015b). Ruşen Çakır ile derinlemesine görüşme. İstanbul. 15 Aralık 2015.

Çakır, R. (2015c). Mirgün Cabas ile Herşey. CNN Türk Televizyonu. 1 Haziran 2015.

Çakır. R. (2015d). AKP'ye oy veren kitlede MHP'li oranı yüzde 8. Habertürk Gazetesi. Erişim 29 Mayıs 2015, http://www.haberturk.com/yazarlar/rusen-cakir2302/1082960-akpye-oy-veren-kitlede-mhpli-orani-yuzde-8

Çakır, R. (2015e). 7 Haziran genel seçimlerine dört gün kala CHP. Erişim 16 Ağustos 2015, https://www.youtube.com/watch?v=JH8v7k8EJp4

Çakır, R. (2017). Ruşen Çakır ile derinlemesine görüşme. İstanbul. 22 Mart 2017.

Dowell, C.T. ve Duncan, D.F. (2016). Periscoping Economics through Someone Else's Eyes: A Real World (Twitter) App. International Review of Economics Education, 23, 34-39.

Edelman, M. (2016). From Meerkat to Periscope: Does Intellectual Property Law Prohibit the Live Streaming of Commercial Sporting Events. Columbia Journal of Law \& the Arts, 39 (4).

Frankel, M. (2015). Fusion Picks: Watch again - Putting up your Periscope. Livestreaming video from a smartphone. Erişim 14 Nisan 2016, http://www.bbc. co.uk/academy/technology/article/art20150520130212810

Funabiki, J. ve Yoshihara, N. (2011). Online Journalisim Enterprises: From Startup to Sustainability. Erişim 03 Mart 2017, http://renjournalism.org/wp-content/ uploads/2012/04/StartuptoSustainability.pdf

Giddens, A. (2008). Sosyoloji. (C. Güzel, Çev.). İstanbul: Kırmızı Yayınları. 
Giles, R. H. (2010). New Economic Models For U. S. Journalism. Daedalus, 139(2), 26-38.

Göker, G. (2016). Bir Gözetim Aracı Olarak Periscope. Çankırı Karatekin Üniversitesi Sosyal Bilimler Enstitüsü Dergisi. 7 (1), 969-992.

Harvey, K. (2014). Encyclopedia of Social Media and Politics. Los Angeles: Sage Publications.

Hermida, A. (2010). Twittering The News. Journalism Practice, 4(3), 297-308.

Huston, C. (2016). Why millions are broadcasting their lives for fun and profit on Periscope. Erişim 14 Şubat 2016, http://www.marketwatch.com/story/whymillions-are-broadcasting-their-lives-for-fun-and-profit-on-periscope-2015-12-22

IPI 2016 Free Media Pioneer Ödülü Medyascope'a. (2016). Bianet. Erişim 2 Mart 2016. http://bianet.org/bianet/medya/172644-ipi-2016-free-media-pioneer-odulumedyascope-a

Jenkins, H. (2006). Convergence Culture, Where Old and New Media Collide. New York: NYU Press.

Kara, M. (2016). Ruşen Çakır'ın geleneksel TV kanallarına kafa tutan girişimi Medyascope'un içinden, Erişim 18 Mayıs 2016, http://webrazzi.com/2016/05/17/ rusen-cakir-geleneksel-tv-kanallarina-kafa-tutan-girisimi-medyascopeun-icinden

Kaye, J and Quinn, S. (2010). Funding Journalism In The Digital Age Business Models, Strategies, Issues and Trends. Peter Lang New York.

Konalı, D. (2016). Ifade özgürlügüne yaratıcı bir katkı: Medyascope, Erişim 10 Haziran 2016, http://www.stuff.com.tr/2016/05/13/ifade-ozgurlugune-yaraticibir-katki-medyascope

Last Month in Periscope. (2015). Erişim 1 Haziran 2015, https://medium.com/@ periscope/last-month-in-periscope-9e6115eb2dfa

Lister, M., Dovey, J., Giddings, S., Grant, I ve Kelly, K. (2009). New Media: A Critical Introduction. (2. baskı). New York: Routledge.

Manovich, L. (2002). The Language of New Media. Cambridge: MIT Press.

McCorvey, J.J. (2015). Periscope Ceo Kayvon Beykpour: "Periscope Has Become A Medium That Can Build Truth and Empathy" Erişim 23 Ocak 2016, http://www.fastcompany.com/3048641/creative-conversations/periscope-hasbecome-a-medium-that-can-build-truth-and-empathy

Medyascope hakkında (2015). Erişim 6 Ocak 2016, http://medyascope.tv/ hakkinda

Newman, N. (2009). The Rise Of Social Media And Its Impact On Mainstream Journalism. Erişim 16 Nisan 2015, https://reutersinstitute.politics.ox.ac.uk/ sites/default/files/The \%20rise \% 20of\%20social\%20media \%20and\%20its \%20 impact\%20on\%20mainstream\%20journalism.pdf 
Öktemer, C. (2015). Ruşen Çakır röportajı: 'Geleneksel medya yok hükmünde olmaya doğru gidiyor'. Erişim 17 Aralık 2015, http://www.azbilmisozneler. com/2015/11/rusen-cakr-roportaj-geleneksel-medya.html

Pavlik, J. V. (2013). Yeni Medya ve Gazetecilik. (M. Demir ve B. Kalsın, Çev.). Ankara: Phoenix Yayınevi.

Periscope By The Numbers (2015). Erişim 20 Ocak 2016, https://medium.com/@ periscope/periscope-by-the-numbers-6b23dc6a1704\#.5fkjmwg5m

Quinn, S. (2009). Mojo-Mobile Journalism In The Asien Region. Singapur: KonradAdenauer Stiftung.

Reilly, D. (2015). What the future holds for live-streaming apps. Erişim 18 Eylül 2015, http://fortune.com/2015/06/15/periscope-meerkat-future

Rodriguez, R. (2015). Periscope: four ways it's shaking up media. Erişim 6 Mayıs 2015. http://edition.cnn.com/2015/05/26/tech/periscope-android-media

Rosen, J. (2006). The people formerly known as the audience. Erişim 26 Ekim 2015, http://archive.pressthink.org/2006/06/27/ppl_frmr.html

Saka, E. (2012). "Yeni Medya ve Değişen Gazetecilik" Bir Uzmanlık Alanı Olarak Gazeteciliğin Dönüşümü. Pi Pazarlama ve Iletişim Kültürü Dergisi. 11(42), 9-13.

Sakallı, S. (2015). Semih Sakalı ile derinlemesine görüşme. İstanbul. 15 Aralık 2015.

Scott, C. (2015). Covering the refugee crisis on Snapchat and Periscope as 'a day-by-day documentary. Erişim 13 Kasım 2015, https://www.journalism.co.uk/ news/-a-day-by-day-digital-documentary-how-news-outlets-are-covering-therefugee-crisis-on-snapchat-and-periscope-/s2/a567769

Sirkkunen E. ve Cook, C. (2012). Chasing Sustainability on the Net. Erişim 10 Mart 2017, http://tampub.uta.fi/bitstream/handle/10024/66378/chasing_sustainability_ on_the_net_2012.pdf

Şahin, M. (2016). Geleneksel Medyanın Yeni Rakibi: Yeni Medya ve Canlı Yayınlar. Yeni Medya. 1, 50-63.

Tunç, A. (2016). Başka bir ana akım medya mümkün mü? Erişim 14 Ocak 2016, http://platform24.org/yeni-medya-yeni-teknoloji/1292/baska-bir-ana-akim-medyamumkun-mu-

Türkiye'de bazı haber sitelerine erişim engeli (17 Temmuz 2016). Erişim 21 Ağustos 2016, http://www.bbc.com/turkce/haberler-turkiye-36819421

$\S$ Volkmer, I. ve Firdaus, A. (2013). Between Networks and 'Hierarchies of Credibilitiy'. Navigating Journalistic Practice In A Sea Of User-Generated Content. C. Peters ve M. Broersma (Ed.). Rethinking Journalism içinde. (101-113). New York. 
Wagner, K. (28 Nisan 2015). Periscope added a million users in its first 10 days. Erişim 10 Mart 2017, http://www.recode.net/2015/4/28/11562002/periscopeadded-a-million-users-in-its-first-10-days

Warren, C. (2015). Apple names the best iOS apps of 2015. Erişim 01 Şubat 2016, http://mashable.com/2015/12/09/apple-best-ios-apps-2015/\#5avAUd7cePqi 